\title{
Effect of Nutrition and Pruning Methods on Productivity and Quality of Cucumber Hybrids in Greenhouse
}

\author{
Badr $^{1}$, L.A.A, M.M.El-Nagar' ${ }^{1}$, S.M. Aly ${ }^{2}$ and M.A.Saad ${ }^{2}$ \\ 1-Department of horticulture, fac.Agric. moshtohor, Banha univ., Egypt \\ 2- Department of horticulture, Agric. Res. Cent., Egypt
}

\begin{abstract}
Two experiments were carried out on cucumber (Cucumis sativus. L) under greenhouses conditions at Kaha Research Farm, Hort. Res. Inst., ARC, Egypt during successive spring seasons of 2014 and 2015 to compare the effect of NPK fertigation rates and some pruning types on the fruit quality, yield, and minerals contents of some cucumber hybrids grown under plastic greenhouse conditions. The investigation consisted of three fertilization levels i.e. $75 \%, 100 \%$ and $125 \%$ from the recommended dose of NPK fertilizers, two pruning methods (one shoot and two shoots/plant) and two cucumber $\mathrm{F}_{1}$ hybrids i.e. Sina 1 and Sina 2 were used. The results indicated that cultivar Sina 2 was the best comparing with the Sinal concerning yield and fruit characteristics, fruit mineral contents (nitrogen, phosphorus and potassium), ascorbic acid and total sugars. Similar results were obtained by using pruning plants on one branch per plant. Using 125\% from the recommended doses of NPK fertilizers gave the highest values of yield and different fruit characteristics, fruit mineral contents (nitrogen, phosphorus and potassium), ascorbic acid and total sugars content compared with the other treatments. The highest values for fruit characteristics N,P,K, TSS, and V.C content in cucumber fruits were obtained from the interaction treatment between cv. Sina1, pruning the plant on one branch and fertilizing with $125 \%$ from the recommended dose of NPK fertilization level.
\end{abstract}

Key words: Nutrition, pruning, cucumber, Hybrids, Greenhouse

\section{Introduction}

Cucumber (Cucumis sativus L.) is one of the most popular and widely grown vegetable crops in the world, one of the oldest vegetables cultivated by early man (Eifediyi and Remison, 2010), as considered the main greenhouse crop in Egypt. Whereas, cucumber fruit is a moisturizer for the human body and reduce the body's need for water. The total numbers of plastic houses in Egypt are 17173 and the cucumber plastic houses are 8408 (Ministry of agriculture, 2015).

With the increasing zeal for its cultivation, the farmers are aptly looking towards improved cultivars to meet out the higher standards of quality and quantity. Among cucumber cultivars, hybrids have really brought the revolution in cucumber cultivation. Many cultivars of cucumber exist with varying shapes and sizes, skin colour and carotene content (Simon, 1992). The variation in the performance of cucumber cultivars has been widely documented by many scholars (Axelson Fors, 1980; Manyvong, 1997), which could be as a result of genetic composition or environmental factors. Greenhouse production technology of cucumber emphasizes the need for proper density in order to boost up the production per unit area by utilizing the available space and nutrients applied. There is not much information available on greenhouse cultivation and its response to varying plant population. There is need to assess the optimum plant density for its cultivation in greenhouses. Cucumber requires a lot of nutrient for proper growth and yield. Thus, the need for fertilizer application is widely recognized as it is readily observed that plants grown in soil with freshly applied fertilizer shows better response to growth and yield. (Cooke, 1972) reported that the major nutrients required by the crop are Nitrogen $(\mathrm{N})$, Phosphorus (P) and Potassium (K). Inadequate supply of any of these nutrients during crop growth is known to have negative impact on the reproductive capability, growth and yield of the plant (Vine, 1953; Solubo, 1972) and supplementary amount of nutrients can be added to soil inform of inorganic fertilizer to correct inadequate supply of nutrients to the crop (Dirk and Hagarty , 1984). Moreover, to their role in increasing meristemic activities and its importance in the metabolism of many constituents such as amino acids, chlorophyll, auxins enzymes and general protein synthesis (Thompson and Troeh, 1978). Use of drip irrigation in the vegetable production, under the greenhouse, causes a restriction of the plant root system spread and that concentrated only in the wetness root zone. For this reason it is requires to the frequent supplying of irrigation water and fertilizers (fertigation) for the root zone soil (rhizosphere), through critical periods of nutrient demand of crop (Mikkelsen, 1989; Kohzushka and Romanets, 1994; Qasim et al., 2008). However, the excessive use of NPK fertilizers create pollution of agro-ecosystem through contamination the underground water with nitrate $\left(\mathrm{NO}_{3}\right)$ and increasing $\mathrm{NO}_{3}$ accumulation in food chain causing hazardous effects, as well as destroy micro-organisms and friendly insects, making the crop more disposed to diseases and reduced soil fertility (Fischer and Richter, 1984; Mahdi et al., 2010). 
In greenhouse vegetables production are greatly dependent on the quantity and quality of the yield, pruning of leaves and side shoot contribute to the ultimate yield in various ways. Training maximized the plant's ability to obtain the sunlight needed for growth (Guo et al., 1991). It is also important to maintain adequate air movement around the plant to reduce risk of fungus and insect problems (http://www.hydro-gardens .com).

Pruning the cucumber plant is important to maintain a proper balance between vegetative growth and fruit load to achieve maximum production of marketable fruits (Humphries and Vermillion, 1994). Gobeil and Gosselin (1990) asserted that pruning is a factor that most likely affects productivity of cucumber. Many varieties of cucumber exist with varying shapes and sizes, skin colour and carotene content (Simon, 1992). The variation in the performance of cucumber varieties has been widely documented by many scholars (Axelson and Fors, 1980; Manyvong, 1997), which could be as a result of genetic composition or environmental factors. The aim of this work was to investigate the effect of NPK fertigation rates and some pruning types on the vegetative growth, fruit quality, yield, and minerals contents of some cucumber hybrids grown under plastic greenhouse conditions.

\section{Materials and Methods}

Two experiments were carried out under unheated plastic houses at Kaha Research Station, Kalubia Governorate during the two successive spring seasons of 2014 and 2015 to study the effect of three fertilization levels and two pruning methods on growth and productivity of two cucumber $F_{1}$ hybrids in greenhouse. The dimensions of the plastic house are $9 \times 60 \times 3.5 \mathrm{~m}$. Cucumber seeds hybrids Sina1 and Sina 2 were sown in speedling trays ( 84 cells) on February $3^{\text {rd. }}$ and $1^{\text {st }}$ for the first and second seasons, respectively. The growing media consisted of peat moss and vermiculite (1:1 volume: volume) and enriched with macronutrients (250g ammonium nitrate, $200 \mathrm{~g}$ super phosphate, $100 \mathrm{~g}$ potassium sulphate and $25 \mathrm{~g}$ magnesium sulphate per peat moss bale) and $50 \mathrm{~g}$ for micronutrients ( $\mathrm{Fe}, \mathrm{Zn}, \mathrm{Mn}$ and $\mathrm{Cu}$ ) as well as fungicides (50g topsen) and $3 \mathrm{~kg}$ calcium carbonate to adjust $\mathrm{pH}$ (Smith, 1971).

\section{Soil characteristics}

Before transplanting the cucumber seedlings, a composite soil sample $(0-30 \mathrm{~cm}$ depth) was taken from the experimental field and important physical and chemical characteristics of the soil were determined by standard methods (Table a). Soil samples were analyzed at Soil, Water and Environment Research Institute, Agriculture Research Center. The chemical properties of the soil were determined using the methods described in Association of Official Agriculture Chemists A.O.A.C. (1990)

Table a. Physical and chemical analysis of plastic house soil in both seasons 2014 and 2015.

\begin{tabular}{|c|c|c|}
\hline \multirow{2}{*}{ Physical analysis: } & \multicolumn{2}{|c|}{ Seasons } \\
\hline & 2014 & 2015 \\
\hline Sand $\%$ & 20.8 & 23.0 \\
\hline Silt $\%$ & 18.40 & 16.80 \\
\hline Clay\% & 60.80 & 60.20 \\
\hline Soil Texture & Clay & Clay \\
\hline \multicolumn{3}{|c|}{ Chemical analysis } \\
\hline \multicolumn{3}{|c|}{ Soluble cations $(\mathrm{meq} / \mathrm{L})$} \\
\hline $\mathrm{Na}^{+}$ & 4.0 & 4.1 \\
\hline $\mathrm{Ca}^{++}$ & 11.43 & 11.29 \\
\hline $\mathrm{Mg}^{++}$ & 6.20 & 6.3 \\
\hline $\mathrm{K}^{+}$ & 0.15 & 0.17 \\
\hline \multicolumn{3}{|c|}{ Soluble anions (meq/L) } \\
\hline $\mathrm{Cl}^{-}$ & 2.0 & 4.0 \\
\hline $\mathrm{HCO}^{--}$ & 1.0 & 1.10 \\
\hline $\mathrm{SO}_{3}^{--}$ & 18.78 & 16.76 \\
\hline $\mathrm{pH}$ & 7.70 & 7.75 \\
\hline $\mathrm{EC}\left(\mathrm{dSm}^{-1}\right)$ & 2.10 & 2.30 \\
\hline Organic matter $(\%)$ & 2.86 & 2.45 \\
\hline \multicolumn{3}{|l|}{ Available elements } \\
\hline $\mathrm{N} \%$ & 1.34 & 1.10 \\
\hline $\mathrm{P} \%$ & 0.17 & 0.18 \\
\hline
\end{tabular}

The plastic house was divided into five ridges. Each ridge was $1 \times 59 \mathrm{~m}$. Two rows of plants were transplanted on each ridge. Cucumber seedlings with three true leaves (20 days old) were transplanted in a greenhouse. The distance between plants was $50 \mathrm{~cm}$ apart, with plant population of 2.2 plant $/ \mathrm{m}^{2}$. Culture practices such as drip irrigation, diseases and insect control were carried out as 
recommended by Ministry of Agriculture, Egypt. Plants were trained vertically by intertwining the main stem with a vertical piece of polyethylene twine suspended from a horizontal, overhead support wire $2 \mathrm{~m}$ above the plant rows.

The treatments were arranged in a split- split plot design with four replicates, where the two hybrids arranged in the main plots, the pruning methods were assigned at random in the sub plots, while the levels of nutrition were randomly distributed in the sub- sub plots.

\section{Treatments used:}

\section{1- Hybrids}

Two hybrids were used, i.e. sina1 and sina2

\section{2-Pruning methods}

Cucumber plants were pruned by removing flower buds and lateral branches on the main stem up to $50 \mathrm{~cm}$ from the base of the plant (or approximately 5-6 nodes). After the previous steps the main-stem and the fruits were developed at the base of each leaf at each node and after 30-35 days of transplanting plants were trained according to different treatments like one shoot and two shoots and staked with the help of nylon threads connected to the wire inside the greenhouse. Other cultural practices and standard plant protection measures were also adopted from time to time to ensure good and healthy crop stand.

\section{3-Levels of fertilization:}

The recommended fertilizers were add as follow a- After 10 days from transplanting for three weeks, add $1.5 \mathrm{~kg}$ ammonium nitrate+ 0.75 Liter phosphoric acid $\left(\mathrm{P}_{2} \mathrm{O}_{5} 85 \%\right)+1 \mathrm{~kg}$ potassium sulphate $+0.75 \mathrm{~kg}$ magnesium sulphate twice week/ greenhouse. In addition foliar nutrition spray ( $1 \mathrm{~g} / \mathrm{liter})$ weekly.

b-After three weeks to before 10 days from the end of experiment, add $3 \mathrm{~kg}$ ammonium nitrate +1.5 Liter phosphoric acid $\left(\mathrm{P}_{2} \mathrm{O}_{5}\right)+3 \mathrm{~kg}$ potassium sulphate $+1 \mathrm{~kg}$ magnesium sulphate/ greenhouse. In addition $1 \mathrm{~kg}$ micronutrient ( iron, zinc, manganese) twice weekly

c- Also add calcium nitrate once weekly.

Three levels of nutrition rates were used as follow: $1-75 \%$ of recommended NPK fertilizers i.e. $2.25 \mathrm{~kg}$ ammonium nitrate, 1.125 Liter phosphoric acid $\left(\mathrm{P}_{2} \mathrm{O}_{5}\right), 2.25 \mathrm{~kg}$ potassium sulphate and $0.75 \mathrm{~kg}$ magnesium sulphate/ greenhouse.

$2-100 \%$ of recommended NPK fertilizer i.e. $3 \mathrm{~kg}$ ammonium nitrate, 1.5 Liter phosphoric acid $\left(\mathrm{P}_{2} \mathrm{O}_{5}\right), 3 \mathrm{~kg}$ potassium sulphate and $1 \mathrm{~kg}$ magnesium sulphate/ greenhouse.

$3-125 \%$ of recommended NPK fertilizer i.e. $3.75 \mathrm{~kg}$ ammonium nitrate, 1.875 Liter phosphoric acid $\left(\mathrm{P}_{2} \mathrm{O}_{5}\right), 3.75 \mathrm{~kg}$ potassium sulphate and $1.25 \mathrm{~kg}$ magnesium sulphate greenhouse.
The levels of NPK fertilizers were added weekly to the greenhouse.

Measurements:

1- Yield

a- Early yield: the early yield was considered as number and weight of fruits picked at the first four harvests.

b- Total yield of fruits: the total yield was considered as total number and weight of fruits for all picks during the harvesting period.

2-Fruit quality:

Data concerning fruit characters were collected when the market flowers reached the marketing fruit size according the E.E.C standard. The following parameters were recorded: a- Average fruit length. b- Average fruit diameter. c- Average fruit fresh weight.

d- Fruit dry weight.

\section{3- Fruit chemical composition:}

Fruit mineral contents: Chemical analysis of fruits were carried out to determine mineral contents.

\section{1- Nitrogen, phosphorus and potassium:}

Nitrogen content was determined in the digested solution by the" Modified micro- Kheldahl" method as described by Plummer (1971), Phosphorus was determined calorimetrically according to the method of Jakson (1973). While potassium was measured using "flam- photometer" as described by Brown and Lilliand (1964).

\section{2- Ascorbic acid.}

It was determined in fruits using 2.6 dichlorophenol indophenol method as described in A.O.A.C. (1990).

3-Total sugars: Total sugars of cucumber fruits were determined using the methods described by Snel \& Shell (1953)

The experimental design: -

All obtained data were statistically analyzed using split -split block design with four replicates, each replicate consisted of five plants for both seasons and the main of different treatment were compared by using the least significant difference test (L.S.D.) at 5\% level of probability (Snedicor and Cochran, 1980).

\section{Results and Discussion}

\section{4-1-Yield and fruit characters:}

Data presented in Table (1) clear the effect of different cultivars ( $F_{1}$ hybrids),pruning, fertilization levels and their interaction on yield and fruit characters of cucumber plants expressed as plant yield ( $\mathrm{kg} /$ plant) and total yield $\left(\mathrm{kg} / \mathrm{m}^{2}\right)$, fruit weight $(\mathrm{g})$, fruit length and diameter $(\mathrm{cm})$ under greenhouse condition during 2014 and 2015 seasons. 
Table1. Effect of cultivars, pruning, fertilization levels and their interaction on fruit yield and it components of cucumber plants under greenhouse condition during 2014 and 2015 seasons.

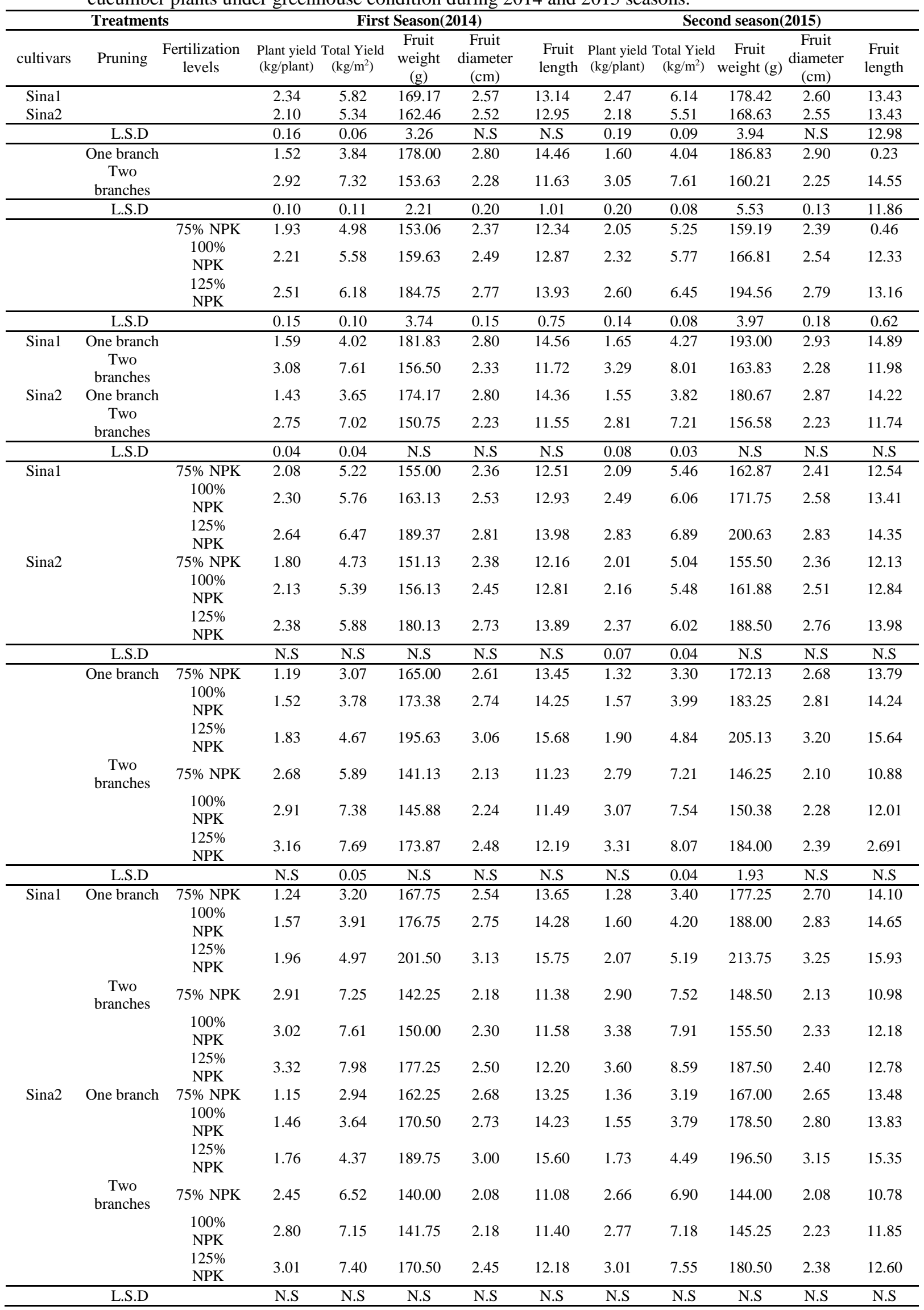




\section{4-1-1-Effect of cultivars:}

The data pertaining to yield and fruit characters as influenced by hybrids have been summarized in Table (1). A perusal of data in Table 1 showed that fruit yield and fruit characters were significantly influenced by the cultivars except fruit diameter during the two season and fruit length during the first season only which did not reach the level of $5 \%$ significance. Significantly highest fruit yield and fruit characters of $2.340 \mathrm{~kg}, 5.82 \mathrm{~kg} / \mathrm{m}^{2}$, $169.17 \mathrm{~g}, 2.57 \mathrm{~cm}$, and $13.14 \mathrm{~cm}$ for plant yield ( $\mathrm{kg} / \mathrm{plant})$, total yield $\left(\mathrm{kg} / \mathrm{m}^{2}\right)$, fruit weight $(\mathrm{g})$, diameter $(\mathrm{cm})$, and fruit length respectively during the first season, were obtained from cultivar Sina 1 which was significantly higher than the cultivar Sina 2. The higher fruit yield $\left(\mathrm{kg} / \mathrm{m}^{2}\right)$ and comparatively better performance of hybrid Sina 1 over hybrid Sina 2 could be ascribed to more number of higher fruit weight, higher fruit length fruit yield per plant (Table 1) such differences in fruit yield. Significant variation for fruit yield between cucumber cultivars have been also reported by Cardoso (2006); Utobo et al. (2010); Bisht et al. (2010); Odaa (2015) and Sharma (2016).

\section{4-1-2-Effect of pruning:}

Concerning the effect of pruning types on fruit yield and fruit characters under greenhouse conditions, data at Table (1) show clearly that pruning the plants to two branches recorded significantly higher fruit yield $\mathrm{kg} /$ plant and total fruit yield $\mathrm{kg} / \mathrm{m}^{2}$ than plants trained to one branch during the first and second season. Meanwhile pruning the plants to one branch recorded significantly higher fruit characters (fruit weight, fruit diameter and fruit length) than plants trained to two branches.The reason for more weight, length and diameter of the fruits harvested from one branch plants was probably due to the better exposure of the plants to light, enhanced synthesis of photosynthates and more assimilation of carbohydrates. These results are in conformity with the earlier findings of Aniekwe and Anike (2015), Oga and Umekwe (2015), Sharma (2016).

Moreover, the higher yield from the plants trained to two branches may be attributed to its better performance in yield per plant which ultimately resulted in increase in yield per $\mathrm{m}^{2}$.Similar results were also reported by Utobo et al. (2010); Sharma (2016)and Mardhiana et al. (2017).

\section{4-1-3-Effect of fertilization levels:}

With respect to the effect of fertilization levels $(75,100$ and $125 \%$ from the recommended doses of NPK fertilizers) on fruit yield and fruit characters of cucumber plant under greenhouse conditions, the results showed that increasing NPK fertigation rate was associated with significant increments in plant fruits yield, total fruit yield $/ \mathrm{m}^{2}$, average fruit weight, fruit length and diameter (Table 1). The highest significant meanvalues of all above mentioned characters were resulting from the highest NPK fertigation rate (125\% of recommended) in both seasons the positive effect of increasing NPK fertilizers on fruit yield and its components may be attributed to the enhancing effect of such elements on vegetative growth parameters which affect consequently on physical quality of produced fruits. These results are in accordance with those obtained by Jilani et al. (2009) and Feleafel et al. (2014) who found that application of NPK fertigation up rate $125 \%$ showed better results for more fruits per vine, maximum fruit weight, vine length and total yield. Therefore, Pushpendra and Hardaha(2016) indicated that the number of fruits per plant, fruit weight per plant, fruit number per plant and total yield per hectare were increased significantly with increase NPK fertilizer application.

\section{4-1-4-Effect of the interaction between tested cultivars and pruning:}

Concerning the effect of the interaction treatments between the studied cultivars and pruning types on the fruit yield and fruit characters, data at table (1) reveal that the highest significant differences were found in fruit yield (kg/plant) and total fruit yield $\left(\mathrm{kg} / \mathrm{m}^{2}\right)$ among the studied cultivars due to pruning the plants on two branches during both the growing seasons of study. Meanwhile, data on fruit length, diameter and weight in Table (1) indicated that interaction effect of cultivars and pruning systems was found to be non-significant effect on these characters during 2014 and 2015 season of studies average fruit weight, fruit length and diameter gave the highest values in such due to pruning the plants on one branch combined with cv. Sina1.These results are in conformity with the earlier findings of Oga and Umekwe (2015) and Sharma (2016).

\section{4-1-5-Effect of interaction between different cultivars and different used fertilizer levels:}

As the effect of combination treatments between used cultivars and NPK fertilizers levels, data illustrated at Table (1) show clearly that there were no significant differences in fruit yield and fruit characters of both cultivars sina1 and sina 2 due to the application of NPK fertilizer levels during the first and second seasons except plant fruit yield $(\mathrm{kg})$ and total fruit yield $\left(\mathrm{kg} / \mathrm{m}^{2}\right)$ in the second season which reach significance, The interaction treatment between cv. Sinal with $125 \%$ from the recommended dose of NPK fertilizers level gave the highest values for fruit yield and its components traits which mentioned above during the first and second seasons of growth. Similar results were reported by Eifediyi and Remison (2010); Nwofia et al (2015); Shafeek et al. (2015), Pushpendra and Hardaha(2016) 
4-1-6-Effect of the interaction between pruning and different used fertilizer levels:

As for the effect of combination treatments between pruning types and different used fertilizers levels, data illustrated at Table (1) show clearly that there were significant differences in total fruit yield $\left(\mathrm{kg} / \mathrm{m}^{2}\right)$ treat as a result of the interaction treatments during the two seasons of this study and average fruit weight during the second one only, all other yield and its components characters were not reach the level of significance. The highest values of fruit yield $\left(\mathrm{kg} / \mathrm{m}^{2}\right)$ and fruit weight were obtained from the interaction treatment between pruning the plant on two branches and fertilize with $125 \%$ from recommended dose of NPK fertilizers level compared with other interaction. Treatments whereas, fruit weight, yield length and diameter recorded the highest values with the interaction treatment between pruning the plants on one branch and fertilized with the same NPK fertilizer level (125\% from the recommended dose). These results were true during the two seasons of study. The findings of present investigation are in accordance with the findings of earlier workers Choudhari and More (2002); Mir (2007); Sharma (2016).

4-1-7-Effect of the interaction between all different treatments:

As the effects of the interaction treatments between all used treatments on fruit yield and fruit characters of cucumber plants (plant fruit, total fruit yield $/ \mathrm{m}^{2}$, fruit weight, length and diameter), data in Table (1) indicate clearly that there were no significant differences between all interaction treatments effects on all studies fruit yield and fruit characters during the two studied seasons the interaction treatment between the cultivars sinal and pruning on two branch and fertilization with $125 \%$ from the recommended dose of NPK fertilizers rate recorded the highest values for each of fruit yield per plant and per meter square. Meanwhile, the highest values for fruit weight, length and were obtained whin application of the interaction treatment between the same cultivar (sina1) and pruning on one branch and fertilization with the same level of NPK fertilizers $(125 \%$ from the recommended dose). Similar results were also reported by Mardhiana et al. (2017).

\section{4-2-Chemical content of cucumber fruits:}

Data presented in Tables (2and3) show the effect of different cultivars ( $F_{1}$ hybrids), pruning, fertilization levels and their interaction on chemical composition of cucumber fruits expressed as nitrogen, phosphorus, potassium, total soluble solids, vitamin-c and total sugars contents under greenhouse condition during 2014 and 2015 seasons.

\section{4-2-1- Effect of cultivars:}

As regard to the nitrogen, phosphorus, potassium, total soluble solids, vitamin-c and total sugars contents in cucumber fruit, data presented in Tables (2and3) show significant differences between the two cultivars Sina1 and Sina2 ( $\mathrm{F}_{1}$ hybrids). Sina1 was higher in all chemical composition mentioned traits in cucumber fruits than Sina2 in the two studied seasons. Such increasing in the content of estimated mineral and organic constituents of produced fruits were related with higher chemical constituents of plant foliage which in turn affected on fruit composition. Similar observations were reported by Al-Harbi et al. (1996); Bisht et al. (2010); Dogra (2012) and Sharma (2016).

\section{4-2-2-Effect of pruning:}

Obtained results in Tables (2and3) indicated that the pruning types have a positive effect in nitrogen, phosphorus, potassium, total soluble solids, vitamin-c and total sugars content in cucumber fruit under greenhouse. There were significant differences between all measured chemical compositions. Traits in cucumber fruits as affected by pruning types (one or two branches) during two season of growth. Data cleared that the pruning on one branch gave the higher values for all recorded traits during the first and second seasons compared with two branches. Similar results were obtained by Hong (2000); Ekwu and Utobo (2010).

\section{4-2-3-Effect of fertilization levels:}

NPK fertigation rates seemed to have clear significant effect on nitrogen, phosphorus, potassium, total soluble solids, vitamin-c and total sugars content in cucumber fruit under greenhouse as noticed from the comparisons listed in Table (2and3).The results indicated that the applying NPK fertigation up to $125 \%$ of recommended caused a significant increase in nitrogen, phosphorus, potassium, total solublesolids, vitamin-c but decreased total sugars content in cucumber fruit. These results are true during two season of study. These results are in accordance with those obtained by Darwesh (2002) who found that using recommended dose of NPK caused a marketable increase in plant contents of N, P and K as compared with no mineral fertilization in tomato. Also, yang $\boldsymbol{e t}$ al (2010) stated that with increasing $\mathrm{K}$ rate $(\mathrm{k}$ fertilization) in the range of $240-720 \mathrm{~kg} / \mathrm{ha}$ increased the contents of soluble sugar and ascorbic acid. Moreover, Shafeek, et al.(2015) who indicated that the highest level of NPK fertilizers (100\%) significantly improved the chemical characters of cantaloupe fruits compared to the intermediate and the lowest levels of NPK (75 and 50\%). The highest significant values of vitamin-c were recorded with the highest level of NPK fertilizers. While, no significant differences were detected among the levels of NPK fertilizers on the percentages of total sugars in cantaloupe. 


\section{4-2-4-Effect of the interaction between tested cultivars and pruning:}

Concerning the effect of the interaction treatments between the studied cultivars and pruning types on the chemical content of cucumber fruit, data in Tables (2and3) reveal that no significant differences were found in all studied $\mathrm{N}, \mathrm{P}, \mathrm{K}$ and total soluble soled content of cucumber fruit among the studied cultivars due to pruning the plants on one or two branches during both the growing seasons of study and vitamin c during the first season only. Whereas, total sugars during two season and vitamin-c during two seasons and vitamin-c during the second season only reach the level of significance. Moreover, the highest values in such nitrogen, phosphorus, potassium, total soluble solids, vitamin-c and total sugars contents of cucumber fruits were obtained due to pruning the plants on one branch combined with cv. Sina1 during both season of growth These results are in agreement with Hong (2000) and Sharma (2016).

Table 2. Effect of cultivars, pruning, fertilization levels and their interaction on chemical content of cucumber fruits under greenhouse condition during 2014 and 2015 seasons.

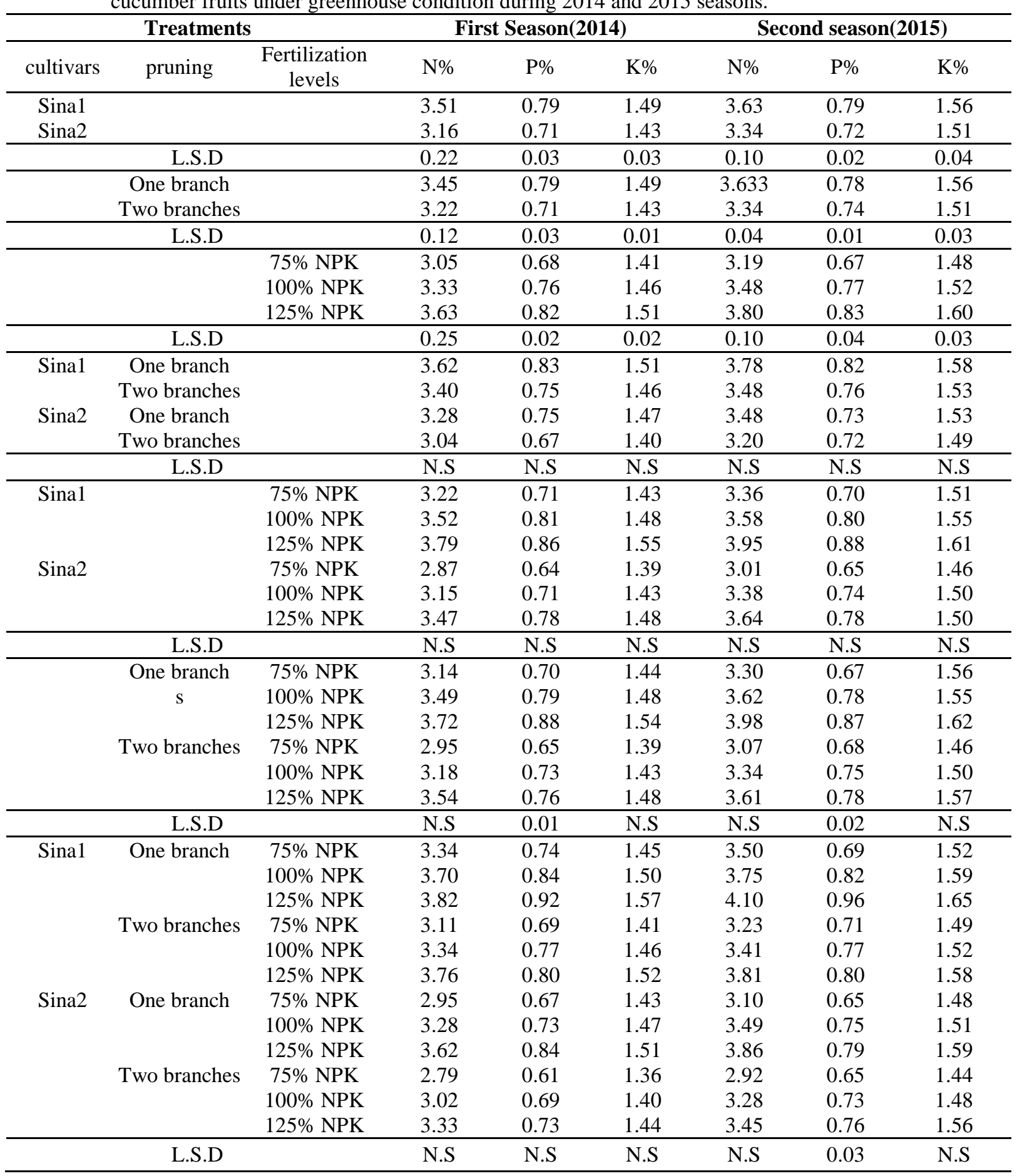


Table 3. Effect of cultivars, pruning, fertilization and their interaction on Tss,v.c and total sugars of cucumber fruits under greenhouse condition during 2014 and 2015 seasons.

\begin{tabular}{|c|c|c|c|c|c|c|c|c|}
\hline \multicolumn{3}{|c|}{ Treatments } & \multicolumn{3}{|c|}{ First Season(2014) } & \multicolumn{3}{|c|}{ Second season $(2015)$} \\
\hline cultivars & Pruning & $\begin{array}{r}\text { Fertilization } \\
\text { levels }\end{array}$ & TSS & V.C & Total sugars & TSS & V.C & Total sugars \\
\hline Sina1 & & & 3.04 & 10.33 & 5.34 & 3.21 & 10.58 & 5.32 \\
\hline Sina2 & & & 2.82 & 9.92 & 4.47 & 3.05 & 10.28 & 4.48 \\
\hline & L.S.D & & 0.07 & 0.26 & 0.08 & 0.12 & 0.24 & 0.20 \\
\hline & One branch & & 3.35 & 11.29 & 5.78 & 3.57 & 11.94 & 5.79 \\
\hline & $\begin{array}{c}\text { Two } \\
\text { branches }\end{array}$ & & 2.51 & 8.96 & 4.03 & 2.70 & 8.92 & 4.00 \\
\hline & L.S.D & & 0.25 & 0.32 & 0.12 & 0.23 & 0.28 & 0.12 \\
\hline & & $75 \%$ NPK & 2.64 & 9.53 & 6.40 & 2.89 & 9.68 & 6.39 \\
\hline & & $100 \%$ NPK & 2.90 & 10.01 & 4.89 & 3.10 & 10.38 & 4.88 \\
\hline & & $125 \%$ NPK & 3.25 & 10.83 & 3.43 & 3.41 & 11.23 & 3.43 \\
\hline & L.S.D & & 0.18 & 0.47 & 0.11 & 0.18 & 0.33 & 0.14 \\
\hline Sina1 & One branch & & 3.46 & 11.47 & 5.87 & 3.64 & 12.39 & 5.84 \\
\hline & $\begin{array}{c}\text { Two } \\
\text { branches }\end{array}$ & & 2.62 & 9.19 & 4.81 & 2.78 & 8.80 & 4.79 \\
\hline Sina2 & One branch & & 3.23 & 11.11 & 5.69 & 2.49 & 11.53 & 5.74 \\
\hline & $\begin{array}{c}\text { Two } \\
\text { branches }\end{array}$ & & 2.41 & 8.73 & 3.25 & 2.62 & 9.03 & 3.22 \\
\hline & L.S.D & & N.S & N.S & 0.05 & N.S & 0.12 & 0.05 \\
\hline Sina1 & & $75 \%$ NPK & 2.69 & 9.58 & 7.15 & 2.99 & 9.76 & 7.08 \\
\hline & & $100 \%$ NPK & 2.99 & 10.29 & 5.29 & 3.15 & 10.58 & 5.29 \\
\hline & & $125 \%$ NPK & 3.44 & 11.13 & 3.59 & 3.49 & 11.40 & 3.59 \\
\hline Sina2 & & $75 \%$ NPK & 2.59 & 9.49 & 5.66 & 2.77 & 9.60 & 5.70 \\
\hline & & $100 \%$ NPK & 2.81 & 9.73 & 4.49 & 3.05 & 10.19 & 4.47 \\
\hline & & $125 \%$ NPK & 3.06 & 10.54 & 3.27 & 3.33 & 0511. & 3.27 \\
\hline & L.S.D & & N.S & N.S & 0.06 & N.S & N.S & 0.07 \\
\hline & One branch & $75 \% \mathrm{NPK}$ & 3.06 & 10.78 & 8.00 & 3.36 & 11.28 & 8.06 \\
\hline & & $100 \%$ NPK & 3.29 & 11.00 & 5.56 & 3.46 & 11.73 & 5.55 \\
\hline & & $125 \%$ NPK & 3.69 & 12.09 & 3.79 & 3.88 & 12.83 & 3.76 \\
\hline & $\begin{array}{c}\text { Two } \\
\text { branches }\end{array}$ & $75 \% \mathrm{NPK}$ & 2.21 & 8.29 & 4.80 & 2.41 & 8.09 & 4.71 \\
\hline & & $100 \%$ NPK & 2.51 & 9.01 & 4.21 & 2.74 & 9.04 & 4.21 \\
\hline & & $125 \%$ NPK & 2.81 & 9.58 & 3.07 & 2.94 & 9.63 & 3.09 \\
\hline & L.S.D & & N.S & N.S & 0.06 & N.S & N.S & 0.07 \\
\hline Sina1 & One branch & $75 \%$ NPK & 3.08 & 10.83 & 8.54 & 3.45 & 11.60 & 8.52 \\
\hline & & $100 \%$ NPK & 3.38 & 11.20 & 5.37 & 3.53 & 12.20 & 5.35 \\
\hline & & $125 \%$ NPK & 3.93 & 12.38 & 3.70 & 3.95 & 13.28 & 3.66 \\
\hline & $\begin{array}{c}\text { Two } \\
\text { branches }\end{array}$ & $75 \% \mathrm{NPK}$ & 2.30 & 8.33 & 5.75 & 2.53 & 7.93 & 5.63 \\
\hline & & $100 \%$ NPK & 2.60 & 9.38 & 5.20 & 2.78 & 8.95 & 5.22 \\
\hline & & $125 \%$ NPK & 2.95 & 9.88 & 3.47 & 3.03 & 9.53 & 3.51 \\
\hline Sina2 & One branch & $75 \% \mathrm{NPK}$ & 3.05 & 10.73 & 7.45 & 3.28 & 10.95 & 7.60 \\
\hline & & $100 \%$ NPK & 3.20 & 10.80 & 5.75 & 3.40 & 11.25 & 5.74 \\
\hline & & $125 \%$ NPK & 3.45 & 11.80 & 3.87 & 3.80 & 12.38 & 3.87 \\
\hline & $\begin{array}{c}\text { Two } \\
\text { branches }\end{array}$ & $75 \% \mathrm{NPK}$ & 2.13 & 8.25 & 3.86 & 2.30 & 8.25 & 3.80 \\
\hline & & $100 \%$ NPK & 2.43 & 8.65 & 3.23 & 2.70 & 9.13 & 3.20 \\
\hline & & $125 \%$ NPK & 2.68 & 9.28 & 2.67 & 2.85 & 9.73 & 2.67 \\
\hline & L.S.D & & N.S & N.S & 0.08 & N.S & N.S & 0.10 \\
\hline
\end{tabular}

4-2-5-Effect of interaction between different cultivars and different used fertilizer levels:

Concerning the interaction treatments between used cultivars and NPK fertilizers levels, data illustrated at Tables (2and3) show clearly that there were no significant differences in $\mathrm{N}, \mathrm{P}, \mathrm{K}$ total soluble solids and vitamin-c content of cucumber fruit traits of both cultivars sina1 and sina 2 due to 
the application of different fertilizer levels, meanwhile, total sugars was significant during the two season of growth. Whereas, the interaction treatment between cv. Sinal and $125 \%$ from the recommended dose of NPK fertilizers level gave the highest N,P,K, TSS and V.C, while the interaction treatment between cv. Sinal and $75 \%$ from the recommended dose of NPK fertilizers level gave the highest value of total sugars content. Such trend was true during both seasons of study. Obtained results were also in agreement with those of Yang $\boldsymbol{e t}$ al.(2010)and Hassan (2015).

\section{4-2-6-Effect of the interaction between pruning and different used fertilizer levels:}

As the effect of interaction treatment between pruning and different used fertilizers levels, data illustrated at Tables (2and3) show clearly that there were significant differences in phosphorus and total sugar content of cucumber fruit treats as a result of the interaction treatments while, nitrogen, potassium, total soluble soled and vitamin-c did not reach the level of significance during the two seasons of this study. The highest values for nitrogen, phosphorus, potassium, total soluble soled and vitamin-c content in fruit were obtained from the interaction treatment between pruning the plant on one branch and fertilize with $125 \%$ from recommended dose of NPK fertilizers level. Meanwhile, the highest values for total sugar content in fruit were obtained from the interaction treatment between pruning the plant on one branch and fertilize with $75 \%$ from recommended dose of NPK fertilizers level. These results were true during the two seasons of study. These results are in agreement with Bisht et al. (2010) and Sharma (2016)

\section{4-2-7-Effect of the interaction between all different treatments:}

As the effects of the interactions between all used treatments on N,P,K, TSS, V.C and total sugars content of cucumber fruit traits of cucumber plants, data in Tables (2and3) indicate clearly that there were no significant differences between all interaction treatments effects on all chemical composition of cucumber fruit during the two seasons of growth, expect phosphorus content of cucumber fruit gave significance differences during the second season only and total sugars during both season of study. The highest values for N,P,K, TSS, and V.C content in cucumber fruits were obtained from the interaction treatment between cv. Sina1,pruning the plant on one branch and fertilize with $125 \%$ from the recommended dose of NPK fertilization level. On the other hand, the lowest values were obtained from cv. Sina2 with two branches and $75 \%$ from the recommended dose of NPK fertilizer level. Moreover, the highest values for sugar content in fruit were obtained from the interaction treatment between Sina 1, pruning the plant on one branch and fertilize with $75 \%$ from recommended dose of NPK fertilizers level followed by the interaction treatment between Sina 2 , pruning the plant on one branch and fertilize with $75 \%$ from recommended dose of NPK fertilizers level. These results were true during the two season of study. These results are in agreement with Bisht et al. (2010); Yang et al. (2010); Hassan (2015) and Sharma (2016)

\section{References}

A.O.A.C. (1990): Association of official Analytical chemists' methods of Analysis Washington, D.C. 2004.

Al-Harbi, A. R., Alsadon, A.A. and Khalil, S. O. (1996). Influence of training system and growing media on growth and yield of cucumber cultivars. Alexandra J. Agr. Res., 41: 355-365.

Aniekwe, N. L. and Anike, N. T. (2015). Effects of Different Mulching Materials and Plant Densities on the Environment, Growth and Yield of cucumber. Journal of Agriculture and Veterinary Science 8: 64-72.

Axelson, F. and Fors, L. (1980). Konkard and Kornett, two $\mathrm{F} \imath$ hybrid cultivars of gherkin from inbullsholm Plant Institute. Horticultural Abstracts 51: 866.

Bisht, B.,Singh, M.P., Srivastva, B.K., Singh,Y.V. and Singh, P.K. (2010). Evaluation of openpollinated varieties and hybrids of cucumber for off-season production under naturally ventilated polyhouse. Indian J. Hortic., 67: 202-205.

Brown, J.D. and Lilliand, M. (1964). Rapid determination of potassium and socilium in plant material and soil extracts by phom photometry, proc. Amer. Soc. Hort. Sci., 48:341-346.

Cardoso, A. I. I. (2006). Minimum harvest number in hybrid cucumber estimated by repeatability coefficient. Bargantia 65(4): 591-595.

Choudhari, S. M. and More, T. A. (2002). Fertigation, fertilizer and spacing requirement of Tropical gynoecious cucumber hybrids. ISHS. Tsukuba, Japan. Acta Hort., 61, 588: 233-240.

Cooke, G. W (1972). Fertilizer for maximum yield. Great Britain: Granada Publishing Limited. pp. 465.

Darwesh, M.A. Fayza. (2002). Effect of different fertilizer sources and levels on growth, yield and quality of tomatoes. Ph.D. Thesis, Faculty of Agriculture, Cairo University, Egypt.

Dirk, A. T and Hargarty, M. (1984). Soil and Plant Analysis. Guide for Agricultural Laboratory Directors and Technologists in Tropical Region, pp. 147.

Dogra, L.K. (2012). Genetic evaluation of some hybrids of cucumber under modified naturally ventilated greenhouse in mid hills of Western Himalayas. M.Sc. Thesis, CSKHPKV, Palampur. 
Eifediyi, E. K., and Remison, S. U. (2010) The effects of inorganic fertilizer on the yield of two varieties of cucumber (Cucumi ssativus L.). Report and Opinion; 2(11):1-5.

Ekwu, L. G., and Utobo, E. B. (2010). Effect of Staking and Pruning on the Growth and Yield of Cucumber (Cucumis sativus L.)Intern. J. Agri. Rural Development 13 N(2)pp.

Feleafel, M. N., Mirdad, Z. M., and Hassan,A. S., (2014). Effect of NPK fertigation rate and starter fertilizer on the growth and yield of cucumber grown in greenhouse. J. Agric Sci. 6(9):81-92.

Fischer, A., Richter, C. (1984).Influence of organic and mineral fertilizers on yield and quality of potatoes. The Fifth IFOAM International Scientific Conference at the University of Kassel, Germany (p. 37).

Gobeil, G. and Gosselin, A. (1990). Influence of Pruning and Season on Productivity of Cucumber Plants Grown in a Sequence Cropping System. Scientia Horticulturae, 41 (3): $189-200$.

Guo, F.C., Fujime, Y., Hirose, T. and Kato, T. (1991). Effect of the number of training shoots, raising period of seedlings and planting density in growth fruiting and yield of sweet pepper. J. Japan. Soc. Hort. Sci, 59: 763-770

Hassan, A. Hassan (2015). Effect of Nitrogen Fertilizer Levels in the Form of Organic, Inorganic and Bio fertilizer Applications on Growth, Yield and Quality of Strawberry. Middle East J. Appl. Sci., 5(2): 604-617.

Hong, Q.( 2000). Effect of pruning and spacing on yield and quality of cucumber. AVRDC Training Report, China p 7.

Humphries, E.G. and Vermillion, D.L. (1994). Pickling cucumber vine pruning treatments and their implications for mechanical harvesting. V37 (1) Trans-ASIA, pp. 71-75.

Jakson, M. L. (1973). Soil chemical analysis prentice-Hall of India private limited, New Delhi, 498 pages.

Jilani, M. S., Bakar, A., Waseem, K. and Kiran, M. (2009). Effect of different levels of NPK on the growth and yield of cucumber (Cucumis sativus) under the plastic tunnel. J. Agric. Soc. Sci., 5, 99-101.

Kohzushka, L. F., and Romanets, V. (1994). Ecological and economic efficiency of mineral fertilizer application as a component of irrigation water. 17th ICID European Regional Conference on Irrigation and Drainage, May 16-22, pp. 209213.

Mahdi, S. S., Hassan, G. I., Samoon, S. A., Rather, H. A., Dar, S. A. and Zehra, B. (2010). Biofertilizers in organic agriculture. J. Phytol., 2, 4254.

Manyvong, V. (1997). Cucumber varietal trial.ARC/AVRDC Training workshop, Thailand .http // avrdc_arc.org.26 pages.
Mardhiana, S.; Ankardiansyah, p. p.; Muh, A.; Dwisantoso, k., and Rizzawijaya, A. (2017) Effects of pruning on growth and yield of cucumber (Cucumis sativus) Mercy variety in the acid soil of North Kalimantan, Indonesia. Cell biology \& development 1 (1): 13-17.

Mikkelsen, R. L. (1989). Phosphorus fertilization through drip irrigation. J. Prod. Agric., 2, 279286.

Mir, A.A.( 2007). Effect of pruning and growth regulators on growth, flowering, fruiting and yield of cucumber.M.Sc. Thesis, Department of Horticulture and Postharvest Technology Sher-eBangla Agricultural University, Dhaka.p 59.

Nwofia, G. E., Amajuoyi, A. N. and Mbah, E. U. (2015). Response of Three Cucumber Varieties (Cucumis sativus L.) to Planting Season and NPK Fertilizer Rates in Lowland Humid Tropics: Sex Expression, Yield and Inter-Relationships between Yield and Associated Traits. Intern. J. Agric. Forestry, 5(1): 30-37.

Odaa, K.H. (2015). Economics of cucumber production under protected agriculture in Babylon province-IRAQ. Intern. J. Current Res., 7(11): 22251-22255.

Oga, I. O. and Umekwe, P. N. (2015). Effects of Pruning and Plant Spacing on the Growth and Yield of Watermelon (Citrullus lanatus L.) in Unwana- Afikpo. Intern. J. Scie. Rese., (4): 110115 April 2016, ISSN (Online): 2319-7064.

Plummer, D.T. (1971): An introduction to practical biochemistry. Mc. Grow Hill Book Company, U k, $278 \mathrm{pp}$.

Pushpendra, S. and Hardaha M.K. (2016) Effect of fertigation levels on growth, quality and yield of polyhouse cucumber(Cucumis sativus $l$ ). Intern. J. Agric. Sci., 8 (43): 1863-1866.

Qasim, M., Ahmad, I. and Ahmad, T. (2008). Optimizing fertigation frequency for Rosa hybrid. Pak. J. Bot., 40, 533-545.

Shafeek, M.R., Shaheen,A.M., Abd ElSamad,E.H., Fatma, A. Rizk and Faten, S. Abd El-Al(2015). Response of Growth, Yield and Fruit Quality of Cantaloupe Plants (Cucumis melo L.) to organic and mineral fertilization. Middle East J. Appl. Sci., 5(1): 76-82, 2015.

Sharma, D. (2016). Effect of spacing and training system on productivity of hybrid cucumber under naturally ventilated polyhouse. M. Sc (Agric. Sci.) thesis, Himachal Pradesh Agricultural University Palampur.p.87.

Simon, P. W. (1992). Genetic improvement of vegetable carotene content,.In D.D. Bills and S.D Kung (eds.). Biotechnology and Nutrition.Proceeding 3rd International Symposium Butterworth - Heinemann. Boston, MA. p. $291-300$.

Smith, G. (1971). Artificial soil mixes. Coop. Ext. Serv. Univ. Geargia. College of Agriculture, 109113. 
Snedecor, G. A. and Cochran, W. G.(1980). Statistical Methods, 7th Ed., the Iowa State Univ., Press, Ames., Iowa, U.S.A. 507 pages.

Snel, F.D. and Shell, C.T. (1953). Colorimetric methods of analysis including some turlidimetric and nephelometric methods D. Van Nastrad Co. Inc.presnceton.New Jersey, Toronto New York, London.666 pp.

Solubo, R. A (1972). Studies on white yam (Discorearo tundata) II. Changes in Nutrient content with Age. Experimental agric., 8: 107115 .

Thompson, L. M., and Troeh, F. R. (1978). Soils and soil fertility MeGraw. New York: Hill Book Company (p. 516).
Utobo, E. B., Ekwu, L.G., Ogah, E.O. and Nwokwu, G. N. (2010). Growth and yield of cucumber varieties as influenced by pruning. Continental J. Agro., 4: 23-27.

Vine, H. (1953). Experiments on the Maintenance of soil Fertility in Ibadan, Nigeria, Emp. J. of Expt 'lAgric., 21: 65-71.

Yang, Y., Xu, F. and Chen, Z. (2010). Effects of potassium fertilization on photosynthetic characteristics and yield of cucumber in solar plastic film greenhouse.Plant Nutri. Fertil. Sci., 16(5):1232-1237. 


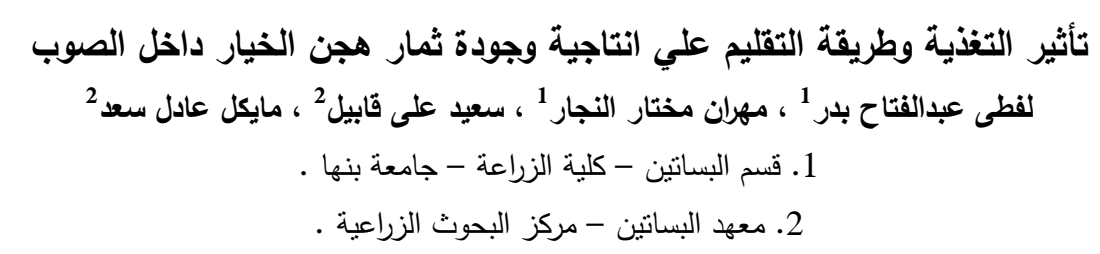

أجريت تجربتان على الخيار تحت ظروف الصوب البلاستيكية في مزرعة قها للأبحاث، معهـ البساتين، مركز البحوث الزراعية، مصر ـ خلال

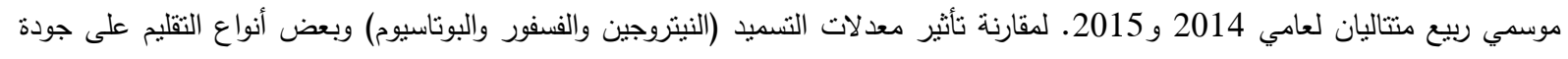

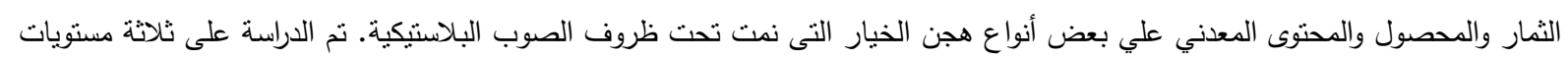

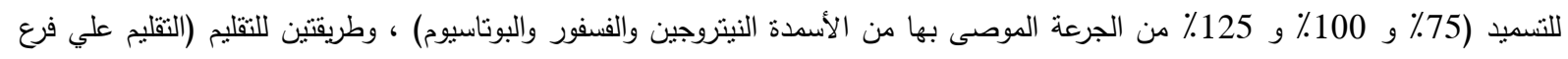

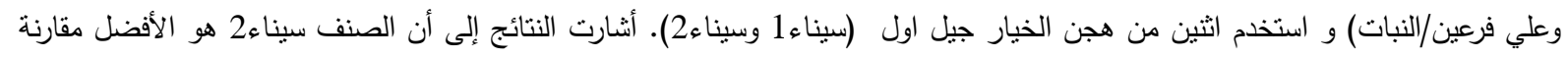

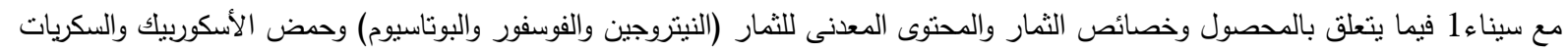

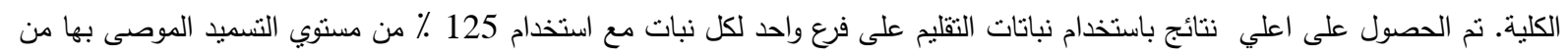

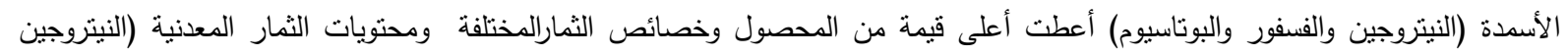

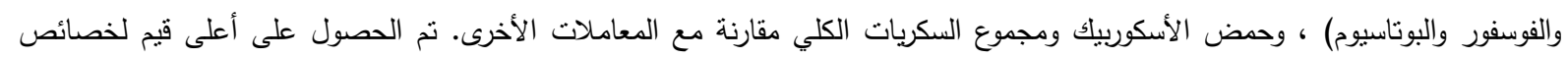

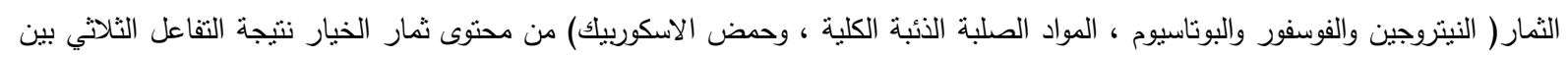

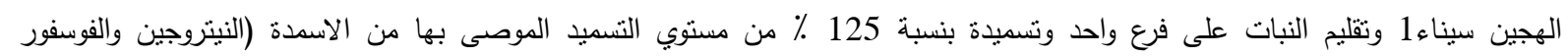
والبوتاسيوم). 